\title{
Condition of Pastures Neighboring to the Villages in Enbekshilder District of Akmola Region and the Effectiveness of Some Surface Improvement Techniques
}

\author{
Aizhan S. Bakhralinova, Akhylbek K. Kurishbayev, Nurlan A. Serekpaev, \\ Gani Zh. Stybayev and Adilbek A. Nogayev
}

Agrotechnical S. Seifullin Kazakh University, 62 Pobeda Avenue, Astana, Republic of Kazakhstan.

http://dx.doi.org/10.13005/bbra/2092

(Received: 05 May 2016; accepted: 04 June 2016)

\begin{abstract}
Studies were carried out on natural community in Enbekshilder district of Akmola region in 2013-2015. We have investigated pasture performance indicators such as botanical composition, projective cover, and yield of pasture mass. In the prevailing meteorological conditions, the projective cover of plant formation of grass/forb pasture was high, the weight of pasture mass ranged from 1.3 to $2.1 \mathrm{t} / \mathrm{ha}$. The efficiency of fertilization was manifested as early as in the first year of studies, the effectiveness of the joint effect of mineral fertilizers with harrowing during the first year of studies was reduced due to partial drying out of the soil in consequence of soil treatment with BIG-3A drag harrow and John Deer 2600 disk harrow. As a result of fertilizer aftereffect, in the second year of studies, in all variants of mineral fertilizers we observed a high crop yield of green mass in total over two years, especially in the variant with application of nitrogen fertilizer. High total crop yield of green mass in the second year of the study was noted also in the variant with the application of nitrogen-phosphorus fertilizer along with the treatment of sod layer by BIG-3A drag harrow.
\end{abstract}

Key words: Pastures, Degradation, Surface improvement, Herbage productivity.

In Kazakhstan there is an urgent need to take measures towards preventing further land degradation and carrying out activities aimed at restoration and sustainable use of natural resources. In 1997, Kazakhstan has committed itself to comply with the provisions of the United Nations Convention to Combat Desertification in Those Countries Experiencing Serious Drought and/or Desertification ${ }^{1}$, which laid basis for developed national program for the rational use of natural resources and prevention of degradation of agricultural land ${ }^{2}$.

\footnotetext{
* To whom all correspondence should be addressed.
}

The total area of natural forage lands in the Republic of Kazakhstan is 186,592.4 thousand hectares, of which 61,123.3 thousand hectares are designated as agricultural land. At that, just 30\% of pastures are used for cattle grazing, because a large part of land is not provided with the water resources that results in creating load on pastures with water availability. Due to the excessive cattle load over the last 25 years, 27,127.7 thousand hectares of land or $15 \%$ of the used pastures underwent degradation. The average grazing performance ranges from 0.4 to $0.5 \mathrm{t} /$ ha depending on the prevailing meteorological conditions. Currently, 6,730.2 thousand hectares of natural forage lands is concentrated on the territory of Akmola region. At that, 4,210.2 thousand ha (63\%) are agricultural lands. The area of disturbed 
(eroded) grassland reaches to 1,931.0 thousand hectares (29\%). Average pasture performance over the past 10 years ranged from 0.4 to $0.6 \mathrm{t} / \mathrm{ha}^{3}$.

In this regard, one of the main tasks of our research was carrying out a comprehensive observation and evaluation of degradation processes occurring in the pastures, in other words - conducting environmental monitoring and development of science-based techniques to improve the natural pastures condition.

The aim of the present research was to examine the current state of the natural community pastures neighboring to the villages of Baymyrza and Birsuat, as well as to study the formation of herbage productivity at stationary experimental plot depending on the various surface improvement techniques.

The set goals were accomplished by addressing the following tasks:

a) Carrying out analysis of meteorological conditions of the area under study in 20132015;

b) Studying the botanical composition of the plant formation of natural pastures neighboring to the Baymyrza and Birsuat villages;

c) Studying projective cover of the plant formation of natural pastures neighboring to the Baymyrza and Birsuat villages;

d) Determining the overground phytomass of natural pastures neighboring to the Baymyrza and Birsuat villages;

e) Studying the effect of nitrogen fertilizer application on the plant formation of native pasture grass;

f) Studying the effect of phosphate fertilizer application on the plant formation of native pasture grass;

g) Studying the effect of sod layer treatment by BIG-3A drag harrow on the plant formation of native pasture grass;

h) Studying the effect of sod layer treatment by modern John Deer 2600 disc harrow on the plant formation of native pasture grass;

i) Studying the effect of joint application of mineral fertilizers and sod layer treatment by John Deer 2600 and the BIG-3A harrows on the plant formation of native pasture grass;

\section{METHODS}

Due to the fact that the ground survey of the condition of ecosystems over large areas is quite complicated problem, it is very popular to evaluate the environmental status of the lands by remote monitoring ${ }^{4-6}$. However, remote monitoring based on finding of correlations between various data, received from the satellite, involves the loss of part of the information as compared with groundbased studies.

The study of forage resources of dry steppes of Kazakhstan, as well as preservation and enhancement of their performance by applying different techniques of surface improvement and amelioration has been carried out by many researchers ${ }^{7-12}$. However, the issues of mineral fertilizers application efficiency together with the treatment of sod layer without seeding of forage grasses is studied poorly, especially with regard to the steppe zone of Akmola region.

The phytocenological method of pastures assessment in Enbekshilder district of Akmola region was conducted in 2013-2015 in the vicinity of Baymyrza and Birsuat villages. On the basis of phyto-cenological assessment, we have chosen a typical stationary plot of the native pasture and initiated the experiments to study the effectiveness of surface improvement techniques, i.e. application of mineral fertilizers and sod layer treatment that was carried out in 2014-2015.

To determine the plant formation status in the vicinity of Baymyrza and Birsuat villages, 10 plots were selected, different in terms of various structures of vegetation layer, but typical for a given investigation zone (Figure 1).

An analysis of meteorological conditions was carried out on the basis of the data obtained from meteorological station located in the village of Stepnyak, which was $50 \mathrm{~km}$ away from the studied pastures. The calculation of the hydrothermal coefficient was carried out according to the Selyaninov method ${ }^{13}$. When conducting phyto-cenological evaluation of pastures, botanical description of the plant formation was carried out according to determinants ${ }^{14,15}$, the definition of the projective cover of plant formation was conducted using Ramensky method ${ }^{16}$, the elevated phytomass was assessed by cut-sample method employed at small $1 \mathrm{~m}^{2}$ experimental plots with subsequent 
recalculation to 1 hectare using the monitoring technique of hayfields and pastures yields at fieldworks ${ }^{17}$.

The mineral fertilizers application rates were calculated based on the actual content of nutrients available in the soil ${ }^{18-22}$. The density of plant formation was determined by counting the number of plants at fixed $1 \mathrm{~m}^{2}$ plots, weight of green mass was determined by grass mowing at fixed (permanent) plots with an area of $50 \mathrm{~m}^{2}$ using the hayfields and pastures yield monitoring technique in stationary experiments ${ }^{17}$.

In accordance with the experimental design, the agricultural activities were conducted in the following way. In the spring of 2014 and 2015, after melting of snow cover (in the first decade of April) upon physical maturation of the soil, the experimental plots were fertilized directly in the stubble by grain stubble seeder (SZS-2.1), equipped with a sharpened iron pipe on paw planter. The following fertilizers were applied at a depth of 6 $\mathrm{cm}$ : nitrogen fertilizer - ammonium nitrate $\left(\mathrm{NH}_{4} \mathrm{NO}_{3}\right)$ - at the rate of $45 \mathrm{~kg}$ a.g. (130 kg/ha in physical weight), and phosphoric fertilizer - standard superphosphate $\left.\left(\mathrm{CàH}_{2} \mathrm{PO}_{4}\right) 2 \times \mathrm{H}_{2} \mathrm{O}+2 \mathrm{CaSO}_{4}\right)$ - at the rate of $75 \mathrm{~kg}$ a.g. (310 kg/ha in physical weight). Depending on experimental variants, fertilization was followed by sod layer treatment employing BIG-3A and John Deer 2600 harrows. The total area of experimental plot was $14,348 \mathrm{~m}^{2}$. The single experimental plot area was $126 \mathrm{~m}^{2}$. The experiments were carried out in triple replications.

The experiments were conducted according to the following design: 1) control (the plot with no sod layer treatment and no application of fertilizers); 2) John Deer (tilling by disk harrow John Deer 2600); 3) BIG-3A (tilling by drag harrow BIG-3A); 4) N (application of ammonium nitrate); 5) $\mathrm{N}+$ John Deer; 6) N + BIG-3A; 7) P (application of standard superphosphate); 8) P + BIG-3A; 9) P + John Deer; 10) N + P; 11) N + P + John Deer; and 12) $\mathrm{N}+\mathrm{P}+\mathrm{BIG} 3 \mathrm{~A}$.

\section{RESULTS AND DISCUSSION}

The experimental area of the pasture is located in a steppe zone with sharply continental climate. Pasture plots are represented mainly by southern chernozems, nonspodic soils, slightly alkalinized and solonized soils, as well as medium and shallow soils with low humus content. The survey findings of soils, sampled from the experimental plots, showed that according to Chernenok gradation, studied soils are classified as extremely poor soils in terms of nitrate nitrogen content in the layer of $0-40 \mathrm{~cm}$ ( $>4 \mathrm{mg} / \mathrm{kg}$ of soil), poor soils - in terms of both mobile phosphorus content $(10.01 \mathrm{mg} / \mathrm{kg}$ of soil) and humus content (2.7\%), and reach - in terms of exchange potassium contant ( $410 \mathrm{mg} / \mathrm{kg}$ of soil); at that, $\mathrm{pH}=8.67$.

According to the average long-term data $^{13}$, the total sum of active temperatures above

Table 1. Density of pasture plant formation depending on the surface improvement techniques, plants $/ \mathrm{m}^{2}$

\begin{tabular}{lccc}
\hline Option & \multicolumn{2}{c}{ Number of plants, plants $/ \mathrm{m}^{2}$} & \\
\cline { 2 - 4 } & $\begin{array}{c}\text { 2014 (the direct } \\
\text { effect of fertilizers) }\end{array}$ & $\begin{array}{c}2015 \text { (the direct } \\
\text { effect of fertilizers) }\end{array}$ & Average \\
\hline Control & 36 & 52 & 44 \\
John Deer & 54 & 56 & 55 \\
BIG-3A & 63 & 56 & 60 \\
N & 57 & 68 & 63 \\
N + John Deer & 68 & 72 & 70 \\
N + BIG-3A & 56 & 61 & 59 \\
P & 84 & 76 & 80 \\
P + John Deer & 73 & 74 & 74 \\
P + BIG-3A & 70 & 73 & 72 \\
N + P & 60 & 83 & 53 \\
N + P + John Deer & 47 & 59 & 58 \\
N + P + BIG-3A & 55 & 60 & \\
\hline
\end{tabular}


$+5^{\circ} \mathrm{C}$ (the beginning of the germination of perennial grasses) in studied area is $2526^{\circ} \mathrm{C}$ and accounts for the period from April 22 to October 7 (167 days). The temperature regime during the research period was slightly lower. On average over the three-year period $(2013,2014,2015)$ the temperature $+5^{\circ} \mathrm{C}$ was observed from April 23 through October 6. The total number of days with a specified temperature was 163. The total sum of active temperatures above $+5^{0} \mathrm{C}$ during this period was on average $2298^{\circ} \mathrm{C}$.

The average precipitation for the years of 2013-2015 exceeded the average long-term indicators except for June (Fig. 2).

In terms of the hydrothermal coefficient (HTC) [13], the years of 2014 (HTC =0.97) and 2015

Table 2. Weight of pasture green mass depending on the surface improvement techniques, t/ha

\begin{tabular}{lccc}
\hline \multirow{2}{*}{ Option } & \multicolumn{3}{c}{ Green mass yield, t/ha } \\
\cline { 2 - 4 } & $\begin{array}{c}\text { 2014 (the direct } \\
\text { effect of fertilizers) }\end{array}$ & $\begin{array}{c}\text { 2015 (the direct } \\
\text { effect of fertilizers) }\end{array}$ & Average \\
\hline Control & 1.81 & 1.81 & 1.81 \\
John Deer & 2.00 & 2.00 & 2.00 \\
BIG-3A & 2.10 & 1.88 & 2.00 \\
N & 2.31 & 2.15 & 2.23 \\
N + John Deer & 1.90 & 2.21 & 2.06 \\
N + BIG-3A & 1.88 & 2.34 & 2.11 \\
P & 2.05 & 2.35 & 2.20 \\
P + John Deer & 1.87 & 2.12 & 2.00 \\
P + BIG-3A & 2.23 & 2.08 & 2.16 \\
N + P & 2.20 & 2.80 & 2.50 \\
N + P + John Deer & 2.07 & 2.00 & 2.04 \\
N + P + BIG-3A & 2.15 & 2.33 & 2.24 \\
LSD - 5\% & 0.40 & 0.31 & \\
\hline
\end{tabular}

Table 3. Aftereffect of the fertilizers application on the plant formation density (experiment laid in 2014), plants $/ \mathrm{m}^{2}$

\begin{tabular}{lcc}
\hline Variant & \multicolumn{2}{c}{ Number of plants, plants $/ \mathrm{m}^{2}$} \\
\cline { 2 - 3 } & $\begin{array}{c}\text { 2014 (the direct } \\
\text { effect of } \\
\text { fertilizers) }\end{array}$ & $\begin{array}{c}2015 \text { (the after } \\
\text { effect of } \\
\text { fertilizers) }\end{array}$ \\
\hline Control & 36 & 56 \\
John Deer & 54 & 84 \\
BIG-3A & 63 & 72 \\
N & 57 & 76 \\
N + John Deer & 68 & 104 \\
N + BIG-3A & 56 & 60 \\
P & 84 & 120 \\
P + John Deer & 73 & 100 \\
P + BIG-3A & 70 & 72 \\
N + P & 60 & 64 \\
N + P + John Deer & 47 & 56 \\
N + P + BIG-3A & 55 & 60 \\
\hline
\end{tabular}

Table 4. Aftereffect of fertilizers on green mass weight (the experiment laid in 2014), t/ha

\begin{tabular}{lccc}
\hline \multirow{2}{*}{ Variant } & \multicolumn{3}{c}{ Green mass yield, t/ha } \\
\cline { 2 - 4 } & $\begin{array}{c}2014 \\
\text { (the direct } \\
\text { effect of } \\
\text { fertilizers) }\end{array}$ & $\begin{array}{c}2015 \\
\text { (the direct } \\
\text { effect of } \\
\text { fertilizers) }\end{array}$ & \\
\hline Cont-rol & 1.81 & 1.83 & Total \\
John Deer & 2.00 & 2.25 & 4.64 \\
BIG-3A & 2.10 & 2.30 & 4.40 \\
N & 2.31 & 2.49 & 4.80 \\
N + John Deer & 1.90 & 1.93 & 3.83 \\
N + BIG-3A & 1.88 & 2.26 & 4.14 \\
P & 2.05 & 2.56 & 4.61 \\
P + John Deer & 1.87 & 2.49 & 4.36 \\
P + BIG-3A & 2.23 & 2.41 & 4.64 \\
N + P & 2.20 & 2.43 & 4.63 \\
N + P + John Deer & 2.07 & 2.37 & 4.44 \\
N + P + BIG-3A & 2.15 & 2.52 & 4.67 \\
LSD - 5\% & 0.40 & 0.56 & \\
\hline
\end{tabular}



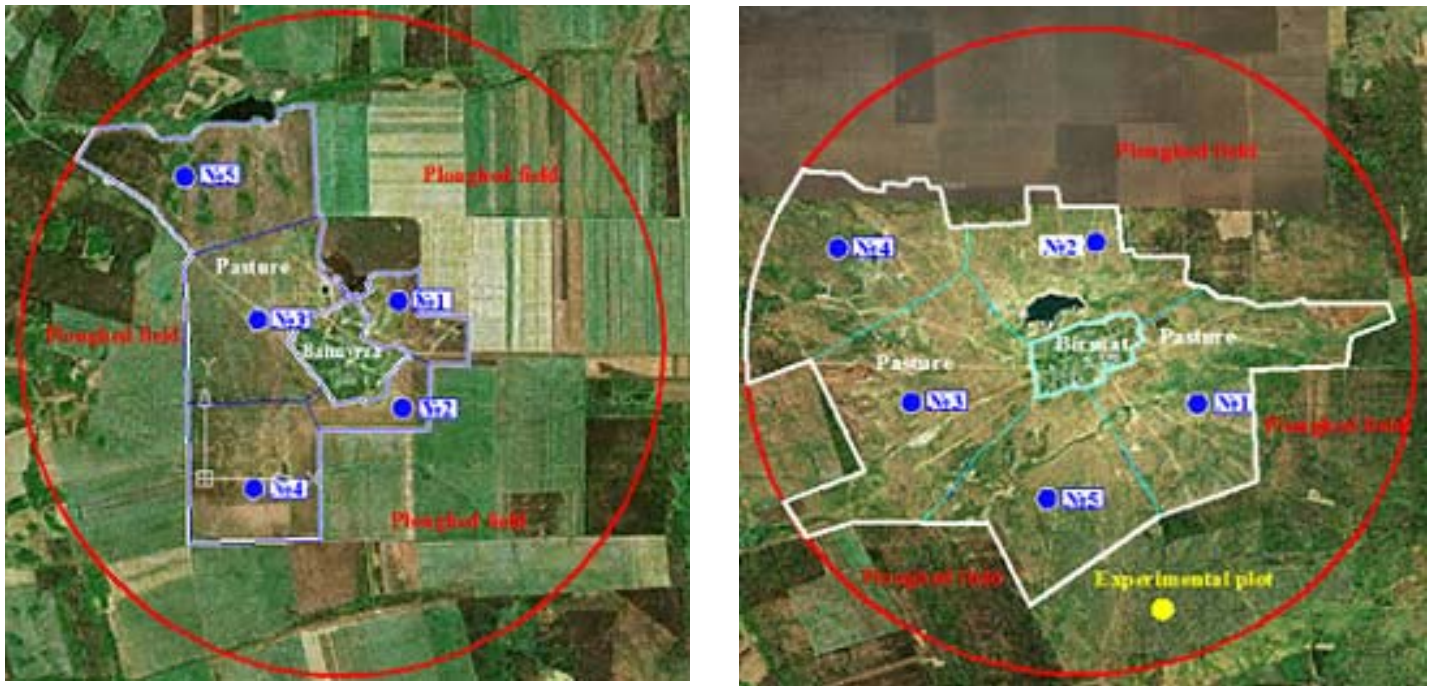

Fig. 1. Location of conditional pastures layouts and the experimental plot to study surface improvement techniques

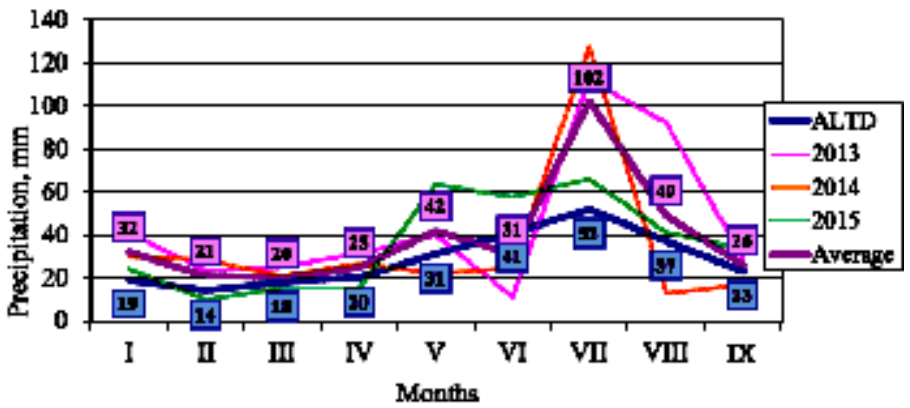

Fig. 2. Precipitation depth in the period of 2013-2015 as compared to the average long-term data (ALTD), mm
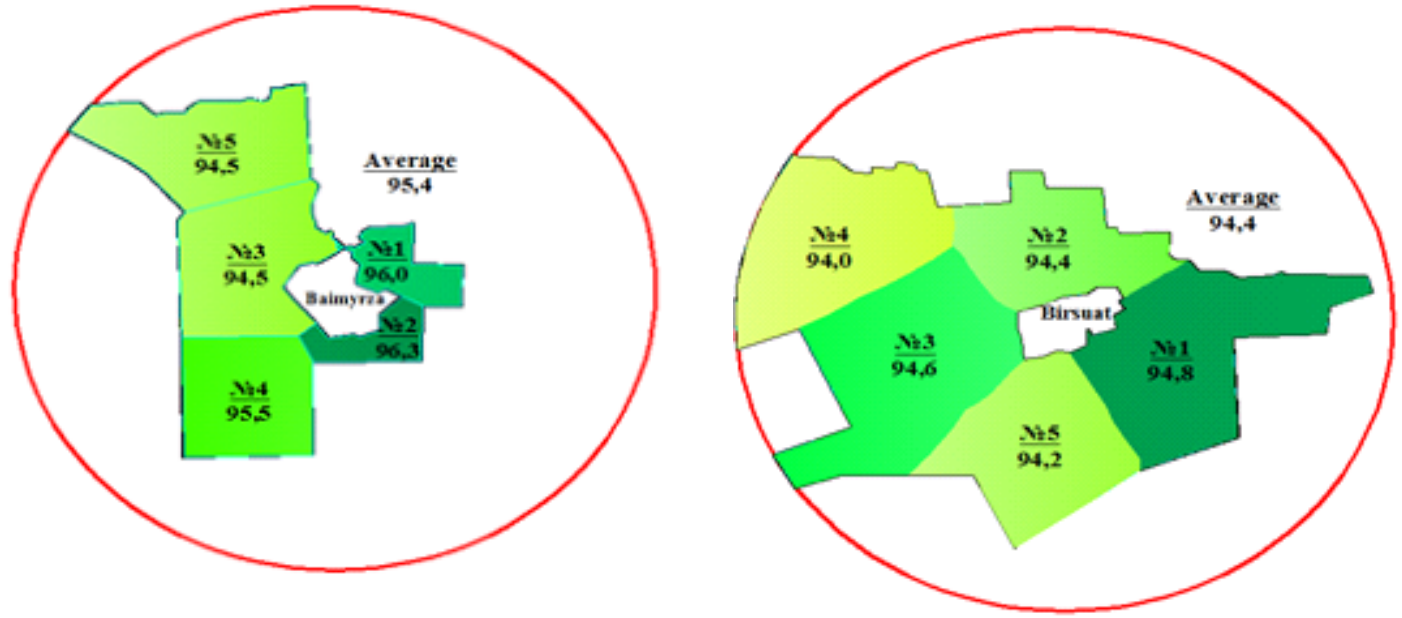

Fig. 3. Projective cover of the experimental pasture plots in Enbekshilder district of Akmola region on average over the three-year period 
(HTC=1.1) were moistened, whereas the year of 2013 turn out to be the most moistened (HTC=1.34). On average over the three-year period, the hydrothermal coefficient was equal to 1.1.

In terms of moist conditions, all three years of research were well provided with precipitation, characterizing by positive distribution mainly in the second half of the

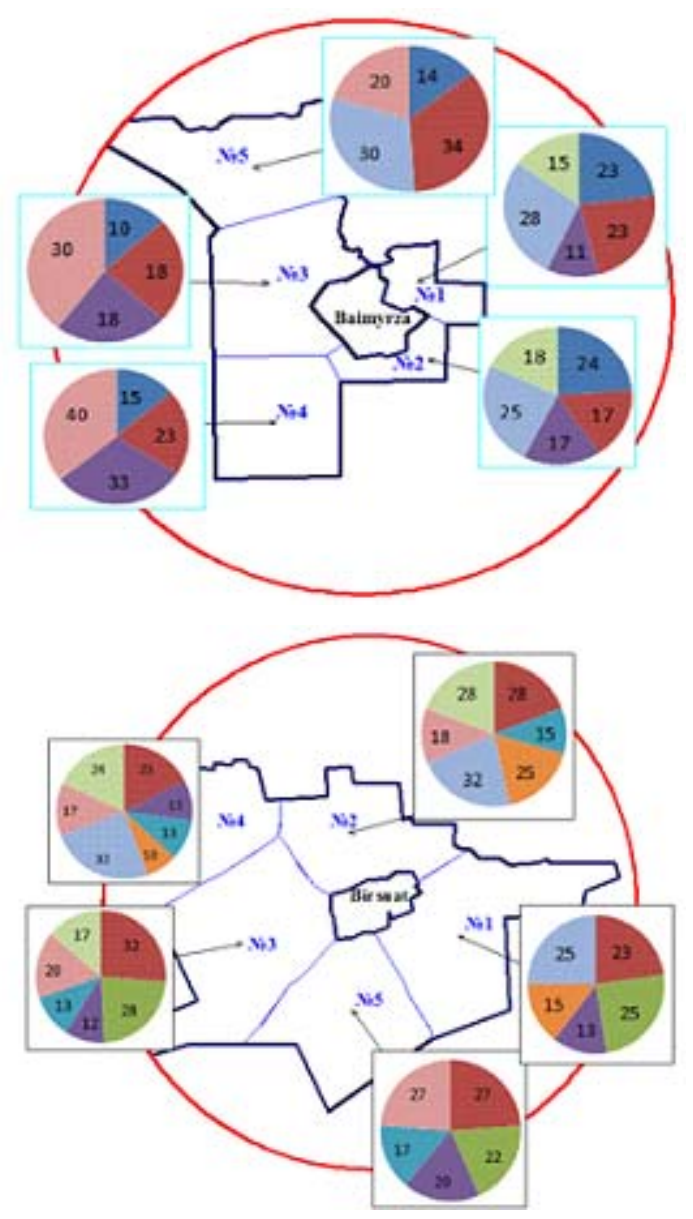

\section{Agropyron cristatum - Stipa lessingiana \\ Bromopsis inermis \\ Elymus junceus \\ Festuca ovina \\ Festuca varia}

Fig. 4. Botanical composition of plant formation in the native paddocks of pastures near Baymyrza and Birsuat villages, plants $/ \mathrm{m}^{2}$, on average over the three-year period summer. This had a positive impact on the growth and development of pasture plants, as well as projective cover, number of plants, weight of green mass, and variety of species.

When carrying out survey of pasture flora (Fig. 3), we defined primarily projective cover indicators by means of Ramensky method ${ }^{16}$.

Over three years of research on experimental plots in the vicinity of the Baymyrza village, the number of quadrates covered by vegetation made up on average $95.4 \%$, in experimental plots near the Birsuat village $-94.4 \%$, whereas empty quadrates amounted to $4.6 \%$ and $5.6 \%$, respectively.

On average over the three-year period of research, no significant difference was observed in projective cover, though the overall proportion

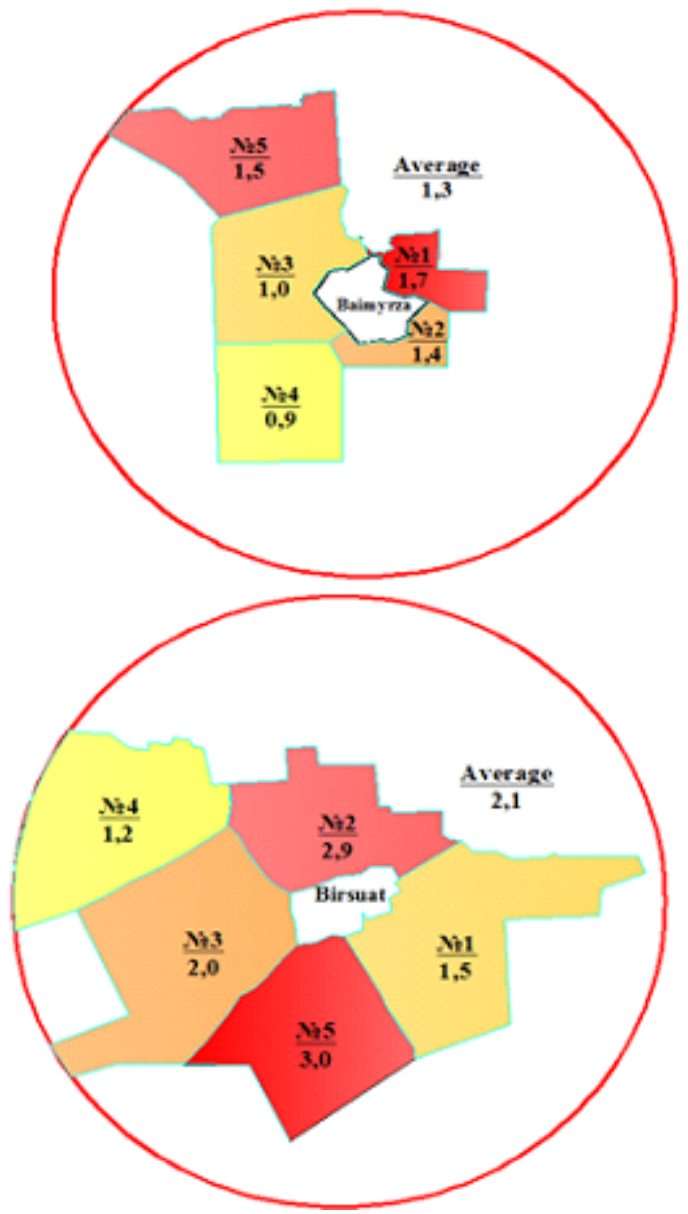

Fig. 5. Performance of studied pasture grassland, hwt/ha, on average over the three-year period 
of plant formation cover in the studied pastures was quite high that is not typical for degraded and tramped pastures.

Figure 4 shows that the studied pasture sites are covered by plants completely different in terms of their forage quality as well as biological and morphological characteristics.

On average over the three-year period of research, on experimental plots of pastures in the vicinity of the Baymyrza and Birsuat villages, the number of plants grown per $1 \mathrm{~m}^{2}$ was 97 and 123, respectively. Among the plants of Poaceae family the following ones were dominated: fairway crested grass (Agropyron cristatum) and awnless brome (Bromus inermis) - around Baymyrza village and awnless brome (Bromus inermis) - around Birsuat village, as well as plants such as Russian wild ruttishness (Elymus junceus), sheep fescue (Festuca ovina), variegated fescue (Festuca varia), Lessing feather grass (Stipa Lessingiana), mugwort (Artemisia vulgaris), Austrian wormwood (Artemisia austriaca), and spring sedge (Carex praecox).

A significant part of pastures is covered by almost ungrazed plant varieties of miscellaneous herbs, such as mugwort (25-32 plants $\left./ \mathrm{m}^{2}\right)$ and Austrian wormwood (17-30 plants $\left./ \mathrm{m}^{2}\right)$. At three sites near Birsuat and at two sites near Baymyrza there are large though very poorly grazed plants of spring sedge (15-28 plants $\left./ \mathrm{m}^{2}\right)$. Other plants, according to reference sources [15.16], are referred to valuable forage grasses. Thus, $100 \mathrm{~kg}$ of fairway crested grass contains 22.7 feed units and $4.1 \mathrm{~kg}$ of digestible protein; $100 \mathrm{~kg}$ of awnless brome contains 29.3 feed units and $3 \mathrm{~kg}$ of digestible protein; $100 \mathrm{~kg}$ of Russian wild ruttishness contains 31.3 feed units and $7.7 \mathrm{~kg}$ of digestible protein. Fescues are less common (11-33 plants/ $\mathrm{m}^{2}$ ); $100 \mathrm{~kg}$ of sheep fescue contains 29.3 feed units and $5.7 \mathrm{~kg}$ of digestible protein; $100 \mathrm{~kg}$ of variegated fescue contains 26.5 feed units and $2.9 \mathrm{~kg}$ of digestible protein; and $100 \mathrm{~kg}$ of Lessing feather grass contains 35.0 feed units and $4.5 \mathrm{~kg}$ of digestible protein.

In addition to determination of botanical composition of certain plots, in consequence of the visual observation of the whole pasture areas, it was revealed that in the vicinity of both villages in some places there were same plants (dispersed throughout the studied pastures and growing in groups of a few plants).

Among the Poaceae family, feather grass (Stipa capillata) was periodically occured. This plant refers to harmful plants due to the fact that it litters animal dander. Among miscellaneous herbs, the following plants were recorded: common yarrow (Achillea millefolium), bastard toadflax (Linaria vulgaris), common dandelion (Taraxacum officinale), sage-leaf mullein (Phlomis tuberosa), rabbit-meat (Lamium purpureum), trailing hollyhock (Hibiscus trionum), plantain rugate (Plantago arenaria), nodding salvia (Salvia nutans), lady's galium (Galium verum), silvery cinquefoil (Potentilla argentea), corn buttercup (Ranunculus abchasicus), blindweed (Capsella bursa-pastoris), as well as Astrodaucus orientalis and beaked parsley (Anthriscus sylvestris), which belong to the Apiaceae family (Apiaceae) and are poorly grazed plants because of the content of essential oils. The pea family was represented by just old-field clover (Trifolium arvense).

Along with the botanical composition of grass stand, the weight of green mass of pasture herbage was determined as well (Fig. 5). Despite the high rates of projective cover and number of plants per $1 \mathrm{~m}^{2}$, the yield of green mass in the experimental plots was very low; thus, it accounted on average over the three-year period for $1.3 \mathrm{t} / \mathrm{ha}$ of green mass from the pastures around the Baymyrza village, and $2.1 \mathrm{t} /$ ha of green pastures around the village of Birsuat.

Thus, the conducted phytocenological rating of pastures near the villages of Baimyrza and Birsuat, situated on the southern chernozems of Enbekshilder district of Akmola region, showed that under conditions of good moistening that prevailed in the years of research, the soil of the surveyed pasture plots was covered by vegetation by $94.4-95.4 \%$. Surveyed areas of native grassland are attributed to grass-forb pasture type with very low performance of 1.3-2.1 t/ha of pasture mass. It was revealed that dense plant formation of experimental pasture plots, though not very productive, is dominated by perennial grasses, namely awnless brome and fairway crested grass.

A comparative survey of plant resources was conducted also after the application of nitrogen and phosphate fertilizers, as well as mixed nitrogen-phosphorus fertilizer, and carrying out according to the experimental design of two kinds 
of surface improvements of sod layer in springs of 2014 and 2015 on a stationary experimental plot with the area of $14.348 \mathrm{~m}^{2}$ located near the Birsuat village.

On average over the two-year period, the density of grass stand in the control variant amounted to 44 plants $/ \mathrm{m}^{2}$ (Table 1 ).

The treatment of sod layer by John Deer and BIG-3A harrows had a positive effect in comparison with the control variant. The grass stand densities amounted to 55 and 60 plants $/ \mathrm{m}^{2}$, respectively. However, the maximum effect on the pasture plant formation density was provided by the application of phosphorus fertilizer; the average stand density in this variant was 80 plants/ $\mathrm{m}^{2}$. The application of a mixed nitrogen-phosphorus (72 plants $/ \mathrm{m}^{2}$ ) and nitrogen (63 plants $/ \mathrm{m}^{2}$ ) fertilizers was less effective. The treatment of previously fertilized soil in the first year of studies does not give a successful result. This is because the treatment of sod layer causes partial drying of the soil that in turn affects the intake of fertilizers by plants.

Green mass yield in the control variant was $1.81 \mathrm{t} / \mathrm{ha}$ (Table 2). The best effect in terms of the green mass weight among the studied techniques of surface improvement is observed in the variants with application of the mixed nitrogenphosphorus fertilizer (2.50 t/ha). The application of nitrogen and phosphorus (2.23 and $2.20 \mathrm{t} / \mathrm{ha}$, respectively) had almost the same effect on the weight of pasture mass.

In the sod layer treatment variants we observed increase in green mass weight in comparison with the control variant. In both variants, at harrowing by John Deer and BIG-3A harrows it amounted to $2.00 \mathrm{t} / \mathrm{ha}$. However, harrowing after application of mineral fertilizers reduces the green mass weight in comparison with the variants of application of mineral fertilizer without treatment of sod layer, similarly as it was noted when analyzing density of grass stand.

Observations and surveys, carried out in 2015 on experimental plots, laid in 2014, showed the effectiveness of mineral fertilizers aftereffect as well as treatment of sod layer (Tables 3-4).

All studied variants revealed significant increase in the density of grass stand. This was especially pronounced in the variant of application of ammonium nitrate in combination with sod layer treatment with John Deer harrow (68 plants $/ \mathrm{m}^{2}$ in 2014 and 104 plants $/ \mathrm{m}^{2}$ in 2015) as well as in the variant with application of standard superphosphate (84 plants $/ \mathrm{m}^{2}$ in 2014 and 120 plants $/ \mathrm{m}^{2}$ in 2015).

As concerns nutrient status of soil, application of nitrogen had the most pronounced effect on green mass weight ( $4.80 \mathrm{t} / \mathrm{ha}$ in total over the two-year period).

In terms of improving water-air regime of the soil, harrowing by BIG-3A (4.40 t/ha in total over the two-year period) was more efficient. When combining fertilization and sod layer treatment, the best variant was the one with application of mixed nitrogen-phosphorus fertilizer and sod layer treatment by BIG-3A harrow ( $4.67 \mathrm{t} / \mathrm{ha}$ in total over the two-year period).

\section{CONCLUSION}

The phytocenological assessment of pastures near villages of Baimyrza and Birsuat, located in the southern chernozems of Enbekshilder district of Akmola region, showed that under good moistening conditions, prevailing in the years of research carried out in 2013-2015, the soil of the surveyed pasture plots was covered with vegetation by $94.4-95.4 \%$. Surveyed areas of natural grasslands are attributed to grass-forb pasture type with very low performance of pasture mass equal to 1.3-2.1 t/ha. It was revealed that the grassland areas, which previously were reseeded by perennial grasses, as well as herbage yielding of experimental pasture plots are dominated by perennial grasses, namely awnless brome and fairway crested grass.

When studying the plant formation of low-performance natural pasture depending on implemented improving techniques of soil nutrition, as well as water and air supply regimes, the following consistent patterns were identified based on average data obtained over the two-year period of 2014-2015:

1) Application of nitrogen (in the form of ammonium nitrate) at a rate of $45 \mathrm{~kg}$ a.g. contributes to increase in plant formation density and weight of green mass. In comparison with the control variant, the number of plants increased by 19 plants $/ \mathrm{m}^{2}$ while yield of green mass - by $0.42 \mathrm{t} / \mathrm{ha}$. 
2) Application of phosphorus (in the form of simple superphosphate) at a rate of $75 \mathrm{~kg}$ a.g. contributes to increase in plant formation density by 36 plants $/ \mathrm{m}^{2}$ and the in the yield - by $0.39 \mathrm{t} / \mathrm{ha}$ comparing to control variant.

3) The regimes with the application of the mixed nitrogen-phosphorus fertilizer (in the form of ammonium nitrate and simple superphosphate) at a rates of 45 and $75 \mathrm{~kg}$ a.g., respectively, showed an increase in the plant formation density by 28 plants $/ \mathrm{m}^{2}$ and in the yield - by $0.69 \mathrm{t} / \mathrm{ha}$.

4) In the first year of research, the treatment of sod layer after application of mineral fertilizers in comparison with the control variant had a positive effect on the number of plants and weight of green mass. However, the imposition of harrowing on fertilized background reduced the efficiency of mineral fertilizers (except for the application of ammonium nitrate together with the treatment of sod layer by John Deer 2600 harrow).

5) Research conducted in 2015 (on the experimental plots laid in 2014) revealed that past annular precipitations, enhanced waterair regime, and aftereffect of mineral fertilizers contributed to enhancement of the efficiency of the studied soil surface improvement techniques. The highest values of green mass weight were noted in the variant with application of nitrogen fertilizer (ammonium nitrate).

\section{REFERENCES}

1. "The United Nations Convention to Combat Desertification in Those Countries Experiencing Serious Drought and/or Desertification” of 7 July 1997, 2016, Retrieved 15.04.2016 from w w w. c a w a t e r - i n f o. n e t/ b k/ water_land_resources_use/russian_ver/pdf/1491-1997.pdf.

2. Bekturova, G.B., 2015, “The United Nations Convention to Combat Desertification: the Situation in Kazakhstan,” Retrieved 15.04.2016 from www.biodiversity.ru/programs/steppe/ bulletin/step-34/opustyn.html.

3. The official website of the Ministry of Agriculture of the Republic of Kazakhstan, Retrieved 15.10.2015 from www.minagri.gov.kz.
4. Esmagulova, B.Zh., Kosheleva, O.Yu., and Mushaeva, K.B., 2015, "Remote Monitoring of the Western Kazakhstan Lands,” Journal of Forestry, 1, pp. 25-34.

5. Lebed, L., Qi, J., and Heilman, P., 2012, “An Ecological Assessment of Pasturelands in the Balkhash Area of Kazakhstan with Remote Sensing and Models,” Environmental Research Letters, 7(2), pp. 1-8.

6. Lebed, L., Qi, J., and Heilman, P., 2008, "Monitoring Rangeland Ecosystems with Remote Sensing: an Example from Kazakhstan,” Environmental Problems of Central Asia and their Economic, Social and Security Impacts, Springer, Netherlands, pp. 135-146.

7. Almanov, Zh.T., Kushenov B.M., and Koshen, B.M., 2013, "Surface Improvement of Degraded Steppe Grassland in Northern Kazakhstan,” Retrieved 12.01.2016 from http://articlekz.com.

8. Baytelenova, A. A., Serekpaev, N. A., and Stybayev, G. Zh., 2014, "Surface Improvement of Pastures in the Conditions of Northern Kazakhstan by Sowing Fairway,” Proceedings of the Cond. " $10^{\text {th }}$ Seyfullin Readings" Astana, pp. 5-8.

9. Zhizylbekov, N.A., Torekhanov, A. A., Smailov, K.Sh., and Alimaev, I.I., 2010, “Natural Resources - the Basis of Kazakhstan Forage Reserve,” Forage Production, 4, pp. 3-5.

10. Mozhaev, N. A, , Kurishbayev, A.K., Serekpaev N. A., Stybaev G.Zh., and Khurmetbek, O., 2014, "Effect of Different Methods of Sod Layer Improvement on Phytocenosis of Southern Chernozems in the Steppe Zone of Akmolinsk Region,” Biotechnicology Biosciences Research Asia, 11(3), pp. 1309-1317.

11. Syzdykov, E.T., and Smailov, G.T., 2013, “Agrobiological Technology for Restoration of Low-productive Grassland in the Steppe Zone of Northern Kazakhstan,” Proceedings of the Int. Conf. on Urgent Problems of Scientific Support of Agriculture of the Republic of Kazakhstan, Kokshetau, 219 p.

12. Khusainov, A.T., 2013, “Environmental Problems of Natural Grasslands of Kazakhstan as the Global Ecosystem of the Biosphere," Bulletin of the Tambov State University, 18(2), pp. 547-551.

13. Mozhaev, N. A., and Serekpaev, N. A., 2009, "Programming of Agricultural Crops Yields," Astana: Kazakh Agrotechnical University named after S. Seifullin, pp. 19-20.

14. Fisyunov, A.V., 1984, "Weed Plants,” Moscow, Kolos, 320 p.

15. Dmitrieva, S.I., Iglovikov, V.G., Konyushkov, N.S., and Ramenskaya, V.M., 1982, "Hayfields 
and Pastures Plants," Moscow, Kolos, 247 p.

16. Ramenskyi, N.T., 1997, "Problems and Studying Methods of Vegetation Cover," Leningrad, Nauka, 336 p.

17. Konyushkov, N.S., Rabotnova, T.A., and Tsatsenkina, I.A., 1961, "Methodology of Experimental Works on the Hayfields and Pastures," Moscow, SELKHOZGIZ, 287 p.

18. Chernenok, V.G., 2009, "Scientific Grounds and Practical Techniques of Soil Fertility and Crops Productivity Management in Northern Kazakhstan,” Astana, Kazakh Agrotechnical University named after S. Seifullin, pp. 24-28.

19. GOST 26213-91, "Soils. Methods for Determination of Organic Matter," 2015, Retrieved 12.03.2016 from www.znaytovar.ru/ gost.

20. GOST-26951-86, “Soils. Determination of Nitrates by Ionometric Method,” 2015, Retrieved 12.03.2016 from www.znaytovar.ru/ gost.

21. GOST 26205-91, “Soils. Determination of Labile Phosphorus and Potassium Compounds by Machigin method modified by the Central Research Institute of Agrochemical Service of Agriculture,” 2015, Retrieved 12.03.2016 from www.znaytovar.ru/gost.

22. GOST-26423-85, “Soils. Measuring Methods of Specific Electrical Conductivity, pH, and Solid Residue of Water Extract,” 2015, Retrieved 12.03.2016 from www.znaytovar.ru/gost. 